\title{
Pierwsze w Królestwie Polskim łukowe mosty systemu Moniera zbudowane przez inżyniera Arnolda Bronikowskiego
}

\section{The First Monier Arch Bridges in the Kingdom of Poland Constructed by Engineer Arnold Bronikowski}

The article lists the first applications of the Joseph Monier patent for the construction of reinforced concrete bridges that took place on the Polish lands. The history of the construction of Monier reinforced concrete arch bridges by Biuro Techniczne Arnold Bronikowski \& S-ka Inżynierowie in the Kingdom of Poland was described on the basis of written sources, iconography, literature and current records. In particular, these included the bridge on the pond in the Ujazdów Park in Warsaw, the Reformacki Bridge on the Rypinowski Canal in Kalisz, the bridge over the Czechówka River in Lublin and the viaduct along the Karowa Street in Warsaw. The basic technical parameters of these constructions, dates of implementation and current status were specified. The life and professional achievements of engineer Arnold Bronikowski were presented in the context of his constructions, both beautiful and innovative at the time. Three of the engineering objects described in the article survived the ravages of war and remain in use today.

Keywords: bridges, viaducts, arches, history of bridge engineering, reinforced concrete, Monier's system

Słowa kluczowe: mosty, wiadukty, łuki, historia techniki mostowej, beton zbrojony, system Moniera

Historia żelbetu rozpoczęła się w 1867 r., w którym francuski ogrodnik Joseph Monier (1823-1906) opatentował donice zbrojone drucianymi siatkami. Jeden z jego kolejnych patentów z 1873 r. dotyczył budowy mostów z betonu uzbrojonego i dwa lata później został zastosowany w kładce o rozpiętości 16,5 m, w parku markiza Tilière w Chazelet we Francji1.

1 M. Thullie, Mosty żelbetowe, Lwów 1921, s. 50. 


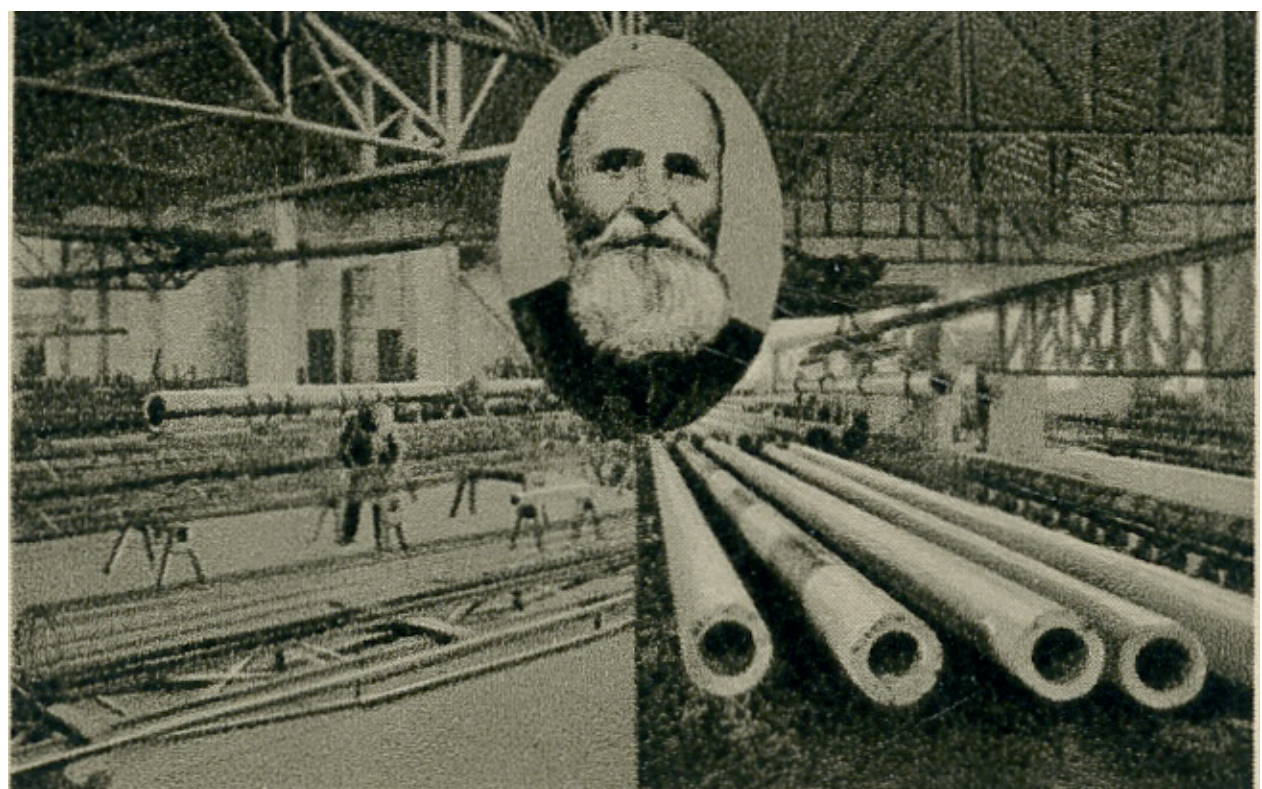

Fot. 1. Popiersie Josepha Moniera na tle zakładu produkującego żelbetowe rury, które opatentował w 1868 r., reklama Zigarettenfabrik Yramos-Dresden (ze zbiorów autora).

W oparciu o uzyskane prawa do patentów technikę betonu uzbrojonego (żelbetu) rozwinął niemiecki inżynier Gustav Adolf Wayss (1851-1917), który w swojej publikacji z 1887 r. nazwał ją systemem Moniera².

Pierwszy na ziemiach polskich most, w którego konstrukcji zastosowano beton uzbrojony według patentu Josepha Moniera, zbudowała w 1891 r. na rzece Rudawie w Krakowie firma „G. A. Wayss \& Cie"3. Najlepiej udokumentowane zostały żelbetowe mosty, które powstały w 1894 r. w Galicji pod zaborem austriackim z inicjatywy środowiska inżynierów Polaków działających w kręgach Szkoły Politechnicznej we Lwowie. W tym samym roku na terenie politechnicznym zbudowano podziwianą do dziś łukową kładkę o rozpiętości w świetle 11,05 m i grubości $10 \mathrm{~cm}$ w kluczu oraz $14 \mathrm{~cm}$ w wezgłowiach, zaprojektowaną przez dr. inż. Maksymiliana Marcelego Thulliego (1853-1939) i zrealizowaną przez inż. Alfreda Zachariewicza (1871-1937) oraz most na Białce w Bielsku z łukiem o rozpiętości $26 \mathrm{~m}$, strzałce 3,04 m i grubości $32 \mathrm{~cm}$ w kluczu oraz $45 \mathrm{~cm}$ w wezgłowiach ${ }^{4}$. Na ziemiach byłego Królestwa Prus, a obecnie polskich, jest użytkowany most przez Kanał Elbląski koło miejscowości Drulity, z żelbetowym łukiem o rozpiętości 26,60 m w świetle, szerokości 6,32 m oraz grubości $56 \mathrm{~cm}$ w kluczu i $90 \mathrm{~cm}$ w wezgłowiach, zbudowany również w $1894 r^{5}$

2 J. Kilby, R. Noyce, Inventors and Inventions Volume 4, New York 2008, s. 1088, 1090. Zastosowania patentu Moniera opisał M. Rybak, Zanim minął wiek XIX - były już mosty z betonu zbrojonego, „Drogownictwo” 2002, nr 7-8, s. 227.

3 J. Jankowski, Mosty w Polsce i mostowcy polscy (od czasów najdawniejszych do końca I wojny światowej), Wrocław 1973, s. 229. Na dawnych fotografiach mostu przez Rudawę nad żelbetowym pomostem widać stalową kratownicę.

4 M. Thullie, Mosty żelbetowe, s. 54. Most na Białce w Bielsku został zburzony przez Niemców w 1945 r.

5 J. Biliszczuk, Mosty w dziejach Polski, Wrocław 2017, s. 108. 
W wydawanym w Warszawie „Przeglądzie Technicznym” Iwowski profesor Thullie opublikował dwa artykuły, w których podał podstawy teoretyczne projektowania konstrukcji żelbetowych. Pierwszy, z 1897 r., dotyczył obliczania płyt, a drugi, z roku następnego, został zatytułowany Obliczenie natężeń w sklepieniach Monier'a. Artykuł ten udostępnił projektantom mostów wzory do obliczania łuków z betonu uzbrojonego ${ }^{6}$. Granice podzielonych ziem polskich, pomimo że były ściśle strzeżone przez wojska państw zaborczych, nie stanowiły zapory dla swobodnego przekazu nowatorskiej wiedzy technicznej, a już szczególnie tej, która była publikowana w języku polskim. Z Galicji wiedza ta bez problemów docierała do Królestwa Polskiego pod zaborem rosyjskim.

Informacje o patencie Josepha Moniera, o pracach teoretycznych prof. Maksymiliana Thulliego i o nowatorskich konstrukcjach mostów zbudowanych w Galicji z pewnością odnotowali pracownicy Biura Technicznego Arnold Bronikowski \& S-ka Inżynierowie, założonego w Królestwie Polskim w przełomowym dla polskiego żelbetu 1894 r. Świadczy o tym reklama zamieszczona w „Tygodniku Illustrowanym”, w której biuro techniczne

poleca specyalnie wielkiej wytrzymałości, i absolutnie ogniotrwałe: Konstrukcye betonowe, syst. «MONIER» mianowicie: sklepienia o dużych rozpiętościach, dachy płaskie, baseny, rezerwoary, wielkie rury, kanały, mosty, wiadukty etc.

Nie zachowały się jednak dokumenty, na których podstawie można byłoby ustalić metody obliczeń i formy rysunków technicznych, stosowane w biurze technicznym przy projektowaniu żelbetowych łuków wykonywanych w oparciu o patent Moniera. Biuro miało siedzibę w Warszawie w prestiżowej lokalizacji, przy ul. Nowy Świat pod numerem $4^{7}$.

Celem niniejszego artykułu jest przedstawienie życia inż. Arnolda Bronikowskiego - założyciela biura technicznego oraz opisanie jego mało znanych osiągnięć zawodowych w dziedzinie budowy pierwszych w Królestwie Polskim mostów z betonu uzbrojonego.

Arnold Bronikowski z Bronikowa herbu Osęk urodził się w 1846 r. w miejscowości Raszkówek w Wielkim Księstwie Poznańskim pod zaborem pruskim. Jego dziadek Wiktor Bronikowski z Bronikowa (1783-1828) był bratem Marcjanny Marianny Prądzyńskiej (1770-1847), której syn, generał Ignacy Prądzyński herbu Grzymała (1792-1850), jako inżynier kierował budową Kanału Augustowskiego, a później w 1831 r. był wodzem naczelnym powstania listopadowego ${ }^{8}$. W Bibliotece Kórnickiej Polskiej Akademii Nauk za-
Fot. 2. Reklama biura technicznego w "Tygodniku Illustrowanym" z 24 sierpnia 1895 r. (Biblioteka Narodowa).
8 Relacja Andrzeja Radoszewskiego przekazana autorowi 23 II 2018 r. 


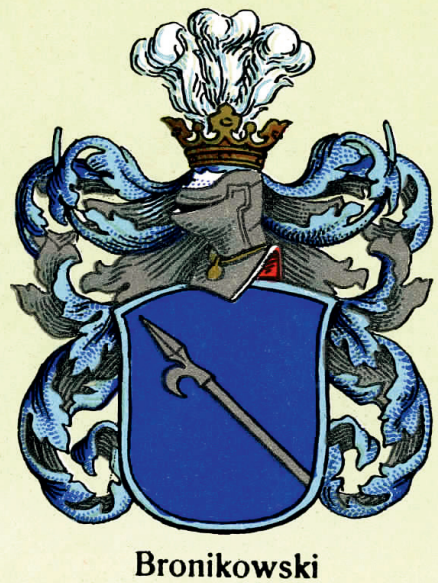

Fot. 3. Herb „Osęk" Bronikowskich wg Zbigniew Leszczyc, Herby szlachty polskiej, Poznań 1908 (ze zbiorów autora). chowały się tzw. „Teki Dworzaczka”" , w których można odnaleźć informację, że 19 września 1869 r. w Farze Św. Magdaleny w Poznaniu odbył się ślub Arnolda Bronikowskiego, politechnika z 23-letnią wówczas Cecylią Wolicką. Niebawem, w 1870 r. urodziła się im pierwsza córka Gabriela, a 31 sierpnia 1871 r. w Tarnowie przyszła na świat kolejna - Leokadia Konstancja ${ }^{10}$.

W sierpniu 1872 r. Arnold Bronikowski ukończył studia techniczne na Politechnice w Zurychu w Szwajcarii i jako młody inżynier rozpoczął pracę zawodową na stanowisku rysownika oddziału budownictwa młynów w zakładach Escher, Wyss i Spółka w Zurychu, którą kontynuował do maja 1873 r. Następnie przeniósł się do Tarnowa w Galicji, aby pracować w fabryce machin i odlewni pod firmą W. Eliaszewicz, w której do stycznia 1875 r. kierował budową maszyn parowych, kół wodnych, tartaków oraz maszyn rolniczych. Dwa lata później zamieszkał na terenie Królestwa Polskiego, gdzie podjął pracę w Towarzystwie Akcyjnym Lilpop, Rau i Loewenstein, zajmując się projektowaniem maszyn parowych oraz instalacji dla cukrowni zlokalizowanych na Wołyniu i Podolu. W styczniu 1876 r. przez krótki czas organizował warsztaty w Końskich, aby ze zdobytym już doświadczeniem od kwietnia 1877 r. do kwietnia 1880 r. pełnić funkcję dyrektora warsztatów mechanicznych w Bliżynie ${ }^{11}$.

4 listopada 1881 r. inż. Bronikowski podjął pracę w Biurze Kanalizacyi i Wodociągów miasta Warszawy jako konstruktor, pod bezpośrednim kierownictwem inż. Wiliama Heerleina Lindleya (1853-1917). Przez pięć lat tej pracy był uznawany za jednego „z najbardziej uzdolnionych mechaników w służbie miejskiej". Po 12 listopada 1886 r. inż. Bronikowski opuścił biuro kierowane przez inż. Lindleya, zatrudniając się w warszawskiej firmie Kuksz i Luedtke. Firma ta rozpoczęła wykonywanie przyłączy domowych do sieci wodociągowej i kanalizacyjnej, a w związku z wieloma zleceniami utworzyła oddział instalacyjny wykonujący „wodociągi, kanalizacyę, przewietrzanie, ogrzewanie oraz roboty żelaznobetonowe". Kierownictwo nowego oddziału zostało powierzone inż. Bronikowskiemu12.

W 1890 r. odbył się ślub córki Arnolda Bronikowskiego - Leokadii Konstancji, z Kazimierzem Sommerem urodzonym w 1860 r. ${ }^{13}$ Męża Leokadii Konstancji można skojarzyć z osobą inż. K. Sommera, którego inż. Bronikowski poznał dużo wcześniej w Biurze Kanalizacyi i Wodociągów miasta Warszawy, a po 1894 r. zaprosił do pracy w swoim własnym biurze technicznym. Hipotezę, że była to ta sama osoba, potwierdza reklama w „Przeglądzie Technicznym" z 1912 r., w której Kazimierz Sommer, z tytułem inżyniera, przedstawia

10 M.J. Minakowski, Wielka genealogia Minakowskiego, wielcy.pl, wydanie z 18 VIII 2018 r.

11 E. Sokal, Wspomnienia pozgonne, „Przegląd Techniczny” r. 33, 1907, nr 46, s. 554.

12 Ibid.

13 M.J. Minakowski, op. cit. 
się jako Generalny Reprezentant na Królestwo i Cesarstwo angielskich samosmarujących pakunków do dławic „Karmal”14 - wyrobów, które wcześniej, w 1897 r., oferowało biuro techniczne inż. Bronikowskiego.

Arnold Bronikowski interesował się sztuką, co wynika z informacji zamieszczonej w „Tygodniku Politycznym, Społecznym i Literackim Prawda" z 1891 r. o przyjęciu go na członka rzeczywistego Towarzystwa Zachęty Sztuk Pięknych w Królestwie Polskim ${ }^{15}$. Zapewne to sztuki piękne inspirowały inż. Bronikowskiego lub projektantów z jego biura technicznego do projektowania mostów nie tylko wytrzymałych i trwałych, lecz również pięknych.

Most na stawie w parku Ujazdowskim w Warszawie był najprawdopodobniej pierwszym drogowym obiektem inżynierskim systemu Moniera oddanym do publicznego użytku na ziemiach Królestwa Polskiego. Tę nowatorską konstrukcję zaoferowało miastu wspomniane wcześniej Biuro Techniczne Arnold Bronikowski \& S-ka Inżynierowie.

Park Ujazdowski został urządzony zgodnie z projektem architekta Franciszka Szaniora (1853-1945), głównego ogrodnika miasta Warszawy, a „sieć wodną parku wykonano wg projektu Lindleya"16. W projekcie parku z pewnością ustalono lokalizację mostu. Przygotowania do budowy mostu podjęto wiosną 1897 r., po wcześniejszym udostępnieniu parku dla publiczności ${ }^{17}$. Zgodnie z projektem parku most miał zostać wykonany z drewna, jednak 22 czerwca 1897 r. „Kurjer Warszawski” poinformował mieszkańców Warszawy, że

z powodu projektowanego urządzenia mostu na stawie w Parku Ujazdowskim, tutejsza firma techniczna A. Bronikowski i Sp. przedstawiła panu prezydentowi miasta do uznania typ mostu betonowego, podług systemu «Monnier». Most z całym przyrządem i balustradą nie ma kosztować całkowitego 1,000 rs. [1 000 rubli - M.M. ${ }^{18}$.

Prezydentem Warszawy był wówczas Rosjanin - generał Mikołaj Bibikow (1842-1923), który strategiczne projekty przekazywał do zatwierdzenia przez właściwe władze Imperium Rosyjskiego. Być może z tego powodu przez ponad miesiąc magistrat miasta Warszawy czekał na skądinąd trudną decyzję o wyborze nie stosowanej wcześniej konstrukcji. „Magistrat otrzymał upoważnienie do oddania robót około pobudowania mostu w parku ujazdowskim firmie "Bronikowski i Spółka» sposobem administracyjnym, za sumę rs. 1,000 [1 000 rubli - M.M.]"19 około 5 sierpnia 1897 r. i dopiero wówczas udzielił stosownego zlecenia biuru technicznemu. Na jego podstawie inż. Bronikowski mógł roz-

14 „Tygodnik Illustrowany” 1897, nr 35, s. bez nr.

15 „Prawda" r. 11, nr 15, s. 180.

16 Wojewódzki Urząd Ochrony Zabytków w Warszawie [WUOZ], Sygn. T.2484 A, Park Ujazdowski Warszawa Aleje Ujazdowskie 6. Recenzja ewidencji parku, autorzy: mgr inż. Zofia Piekarska, mgr inż. Zofia Ziembińska-Sznee, 1988 r., s. bez nr.

17 A. Kozielski, Mostek w Parku Ujazdowskim w Warszawie - przykład wczesnej konstrukcji żelbetowej, „Ochrona Zabytków 1986, nr 1, s. 38-42.

18 „Kurjer Warszawski” r. 77, 1897, nr 170, s. 4-5.

19 „Kurjer Warszawski” r. 77, 1897, nr 214, s. 3. 


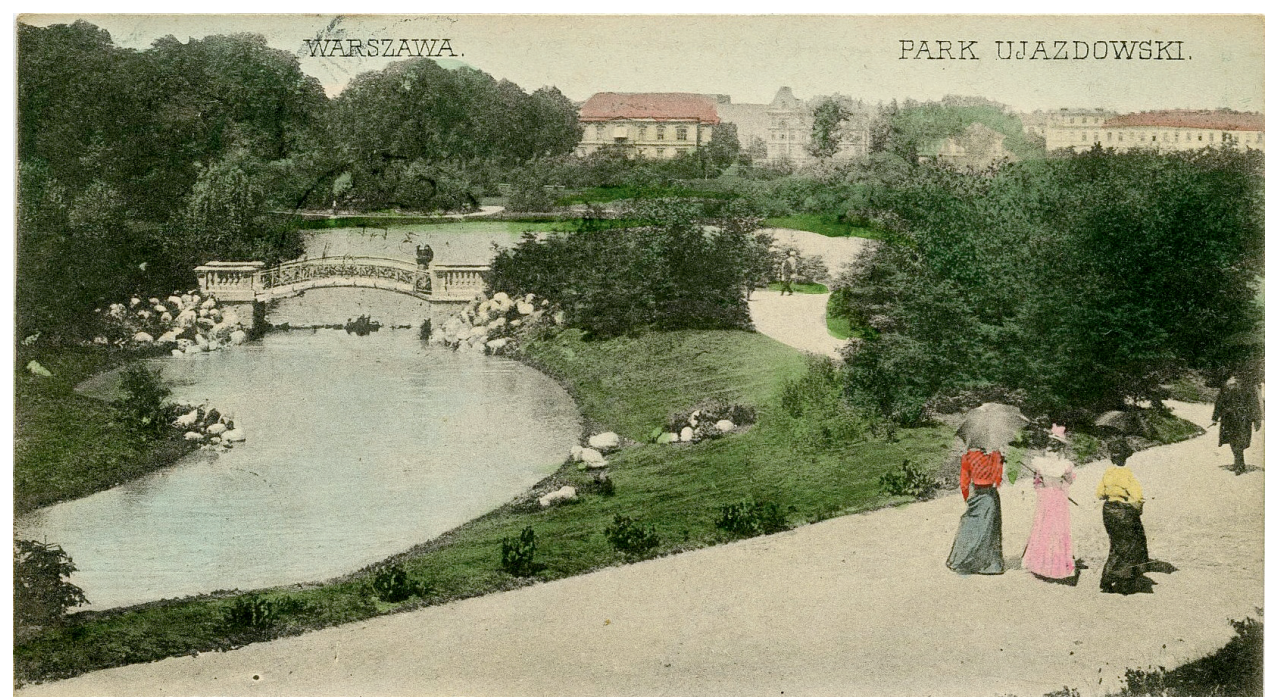

Fot. 4. Park Ujazdowski z mostem na stawie na pocztówce z obiegu ok. 1900 r., Nakład A. Wiszniewskiego w Warszawie, Światłodruk B. Wierzbicki i S-ka Warszawa (ze zbiorów autora).

począć prace projektowe i przygotowawcze, a roboty budowlane ruszyły dopiero po ich zakończeniu, w październiku 1897 r. Do 16 października „stanęły już podstawy, ułożone z ciosanego granitu"20.

Zgodnie ze stanem faktycznym, stwierdzonym w 1985 r. przez inż. arch. Antoniego Kozielskiego, most w parku Ujazdowskim miał mieć konstrukcję łuku o rozpiętości 5,92 m, szerokości 2,66 m i strzałce 0,50 m. Sklepienie łuku miało mieć grubość $8 \mathrm{~cm}$ w kluczu, a w wezgłowiach $16 \mathrm{~cm}$ i zostać zazbrojone dołem prętami wzdłużnymi o średnicy $8 \mathrm{~mm}$ w rozstawie $7 \mathrm{~cm}$ i prętami poprzecznymi o średnicy $6 \mathrm{~mm}$ w rozstawie 7,5 cm. Przyczółki mostu miały zostać wykonane z ciosanego granitu z betonowymi barierami, a łukowy ustrój niosący miał mieć ozdobną balustradę z kutego żelaza ${ }^{21}$.

Po miesiącu prowadzenia budowy, 30 listopada 1897 r., z uwagi na wczesne nadejście zimy magistrat miasta Warszawy wydał nakaz przerwania wszystkich robót budowlanych w mieście ${ }^{22}$. Wznowione wiosną postępowały szybko, ponieważ już 20 maja 1898 r. „Kurjer Warszawski" miał do przekazania mieszkańcom Warszawy bieżące wiadomości

W parku Ujazdowskim w tych dniach ukończony będzie most na kanale, wiodącym do sztucznego wodospadu od stawu. Most ten bardzo ozdobny, zbudowany systemem Monier, na sklepieniach siatkowych, przybrany został wazonami z kwiatami. Wnet po ostatecznem ukończeniu mostu nastąpi nawodnienie stawu, który na czas robót przy moście trzeba było osuszyć. Na stawie tym znajdzie się niebawem

20 „Kurjer Warszawski” r. 77, 1897, nr 286, s. 6. Strona internetowa urzędu m. st. Warszawy zielona.um.warszawa.pl/tereny-zielone/parki/park-ujazdowski [dostęp 26.08.2018], a za nią inne strony internetowe przekazują informację, że projektantem mostu w parku Ujazdowskim jest inż. W.H. Lindley. Tej informacji nie potwierdzają dokumenty przechowywane w archiwum Wojewódzkiego Urzędu Ochrony Zabytków w Warszawie, a falsyfikują ją „Wiadomości bieżące” zamieszczone w „Kurjerze Warszawskim” cytowane pod przypisami 18 i 19.

21 A. Kozielski, op. cit.

22 Ibid. 


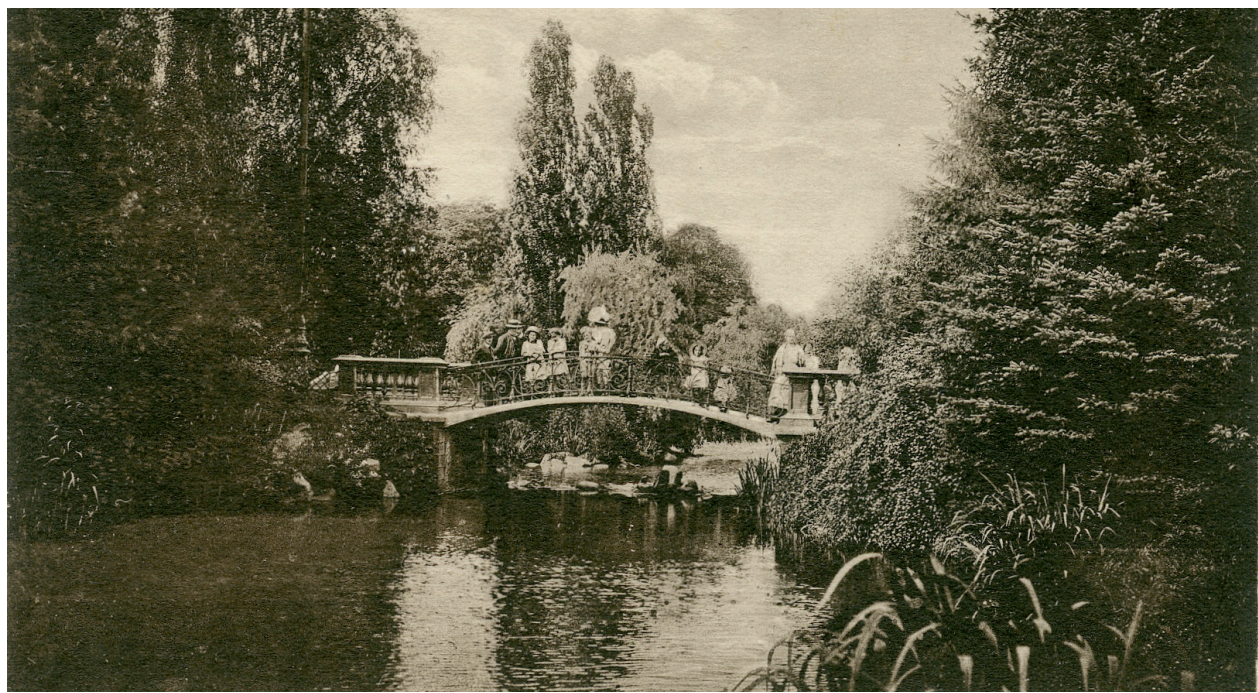

Fot. 5. Most w parku Ujazdowskim w okresie międzywojennym na pocztówce bez obiegu, Składnica i Wydawnictwo Pocztówek K. Wojutyński Warszawa (ze zbiorów autora).

kilka par łabędzi białych i czarnych. W stawie, gwoli czystości, wytworzono stały obieg wody, dostarczanej wprost z rur wodociągowych ${ }^{23}$.

Most na stawie został oddany do użytku zapewne we wzmiankowanym przez prasę terminie, a potem przetrwał dwie wojny światowe, Powstanie Warszawskie 1944 r. i do dzisiaj cieszy oko mieszkańców Warszawy²4.

Most Reformacki na Kanale Rypinowskim w Kaliszu miał być obiektem o wiele większym od mostu w parku Ujazdowskim, a ponadto dostosowanym do dużych obciążeń wywoływanych przez ruch kołowy. Od XVIII w. na przedmieściach Kalisza na trakcie prowadzącym do Wrocławia, tzw. Wrocławskim Przedmieściu, użytkowano mosty o konstrukcji drewnianej, a w 1889 r. w miejscowej prasie po raz ostatni odnotowano wymianę drewnianych bali mostowego pokładu ${ }^{25}$. Z pewnością po 12 latach użytkowania drewno w moście uległo już naturalnemu zużyciu, co postawiło prezydenta Maksymiliana Opielińskiego (1840-1913) i magistrat miasta Kalisza przed koniecznością podjęcia decyzji o jego kolejnej wymianie albo budowie nowego mostu o konstrukcji trwałej.

Zadecydowano o budowie mostu żelbetowego systemu Moniera, zlecając jej realizację Biuru Technicznemu Arnold Bronikowski \& S-ka Inżynierowie z Warszawy. Z wydawanej codziennie „Gazety Kaliskiej” 26 lipca 1902 r. kaliszanie dowiedzieli się, że

23 „Kurjer Warszawski” r. 78, 1898, nr 138, s. 4.

24 W latach 1988-1989 w ramach prowadzonych prac konserwatorskich żelbetowy łuk mostu został wymieniony na nowy o grubości $11 \mathrm{~cm}$ w kluczu i $22 \mathrm{~cm}$ w wezgłowiach, patrz: WUOZ, sygn. -N./War.1101, Dokumentacja prac konserwatorskich mostku żelbetowego z żelazną balustradą w parku Ujazdowskim w Warszawie, Warszawa 1988/89.

25 A. Tabaka, M. Błachowicz, Most Reformacki 1902, „Życie Kalisza”, www.zyciekalisza.pl/?str=82\&id=157107 [dostęp 30.08.2018], s.1. 
Na Wrocławskiem Przedmieściu rozpoczętą została budowa nowego mostu na miejsce starego drewnianego, który uległ zupełnemu zniszczeniu. Nowy most, długości [rozpiętości - M.M.] 13 metrów, wybudowany będzie według najnowszego systemu «Monier», polegającego na połączeniu w konstrukcji żelaza z betonem, i rzucony zostanie przez kanał Prosny w postaci jednego łuku. Sklepienie opierać się będzie na dwóch kamiennych przyczółkach. Budowy powyższego mostu podjęło się Biuro techniczne p. f. Arnold Bronikowski i S-ka, [...] Budowla mostu trwać będzie około 2 miesięcy, a koszta wyniosą 13600 rb. ${ }^{26}$

Rozpoczęte z końcem lipca roboty budowlane przebiegały zgodnie z planem do jesieni, co potwierdza notatka w „Gazecie Kaliskiej” z 13 września, w której czytamy, że budowa mostu „na Wrocławskiem Przedmieściu, systemem Maunier’a [Moniera - M.M.], zbliża, się ku końcowi. Po ukończeniu dwóch filarów, podtrzymujących most, przystąpiono do zakładania wiązania z drutów, na którem spocznie most betonowy"27. Kolejne notatki informują, że 17 października „przystąpiono już do usunięcia belkowania, podtrzymującego dotąd murowane sklepienie mostu, a po obu stronach układać zaczęto chodniki betonowe"28, a 23 października

roboty około wykończenia mostu systemu Maunieur na Wrocławskiem Przedmieściu, około domu Sznerra, postępują bardzo szybko i mają się ku końcowi. Wymurowano już chodniki betonowe po obydwóch stronach mostu, brukowanie którego również rozpoczęto. W tych dniach założoną zostanie bardzo ładna balustrada żelazna, wykonana w zakładzie mechanicznym p. Karola Wegnera ${ }^{29}$.

Żelazna balustrada o secesyjnym wzorze nadała prostej, łukowej konstrukcji stylową, do dziś podziwianą architekturę.

Z ostatniej informacji z „Gazety Kaliskiej” na temat budowanego mostu, z 1 listopada 1902 r., dowiadujemy się, że betonowe chodniki zostały wykonane przez firmę kaliską „J.S. Dobrzyniecki”, a „próba wytrzymałości mostu odbędzie się d. 5-go listopada za pomocą 8 wozów frachtowych z węglami. Ruch tymczasowy dla dorożek i wozów lekkich został już otwarty"30.

Z informacji zawartych w „Książce Obiektu Mostowego” wynika, że obecnie most o długości 21,50 m i szerokości 13,30 m niesie jezdnię o szerokości 7,60 m i dwa chodniki: 3,45-metrowy lewy i 2,25-metrowy prawy. W roku 1991 łukowy ustrój niosący mostu, o rozpiętości teoretycznej 13,15 m, został wyremontowany, a jego nośność ustalono na 15 ton $^{31}$.

Most przez Kanał Rypinowski przetrwał totalne zniszczenie miasta, którego dokonali Niemcy w 1914 r. zaraz po rozpoczęciu pierwszej wojny światowej, został wpisany do

26 „Gazeta Kaliska” r. 10, 1902, nr 199, s. 2.

27 „Gazeta Kaliska” r. 10, 1902, nr 259, s. 2.

28 "Gazeta Kaliska" r. 10, 1902, nr 280, s. 2.

29 „Gazeta Kaliska” r. 10, 1902, nr 286, s. 1.

30 „Gazeta Kaliska” r. 10, 1902, nr 295, s. 2.

31 Miejski Zarząd Dróg i Komunikacji w Kaliszu, „Książka Obiektu Mostowego” JNI:01028013, Most Reformacki, $2000 \mathrm{r}$. 


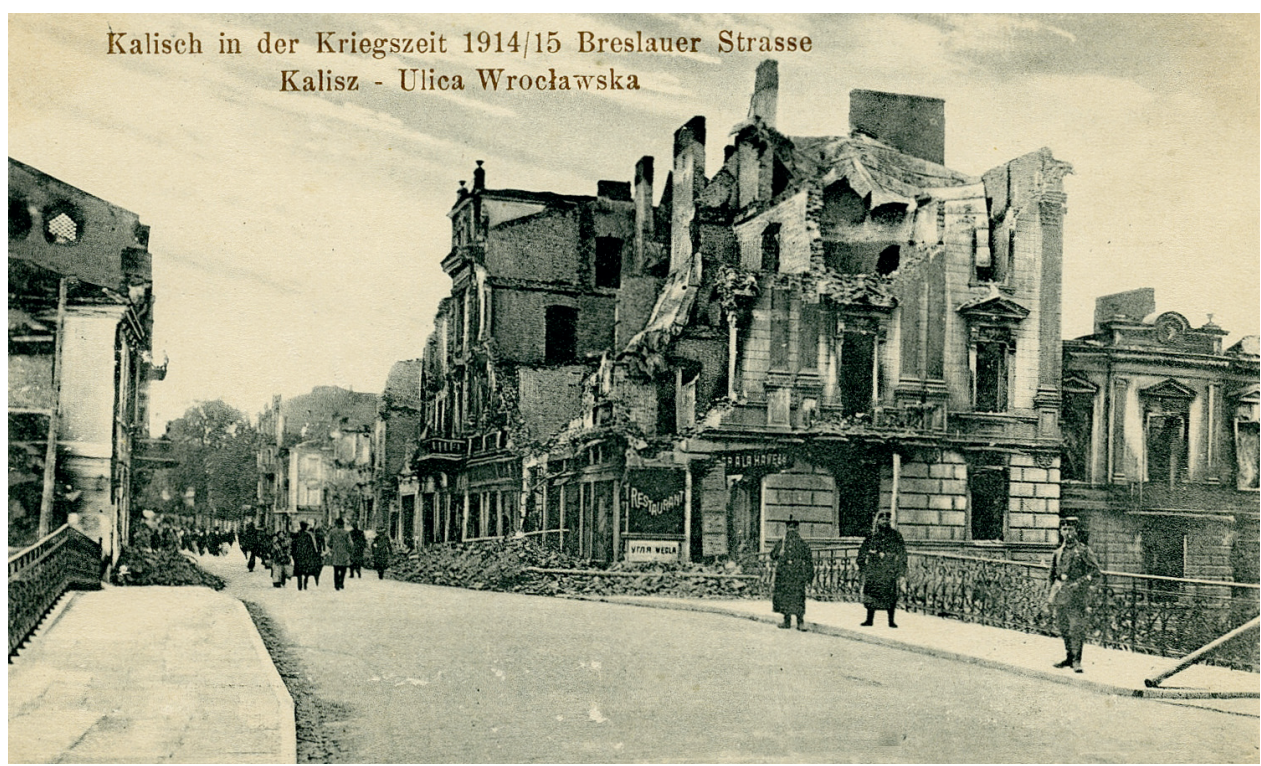

Fot. 6. Most Reformacki na przełomie lat 1914-1915 ze zburzonymi domami Kalisza w tle, na pocztówce bez obiegu, Verlag O. Witzel, Photogr. Atelier, Krotoschin i. P. (ze zbiorów autora).

ewidencji zabytków nieruchomych Urzędu Miejskiego w Kaliszu² i do dzisiaj służy prowadzeniu ruchu kołowego ulicą Śródmiejską.

Most na rzece Czechówce w Lublinie był konstrukcją zbudowaną w systemie Moniera przez inż. Arnolda Bronikowskiego, która po raz pierwszy przysporzyła mu wielu problemów. W 1902 r. w Lublinie postanowiono zastąpić istniejący most drewniany w ciągu ul. Lubartowskiej konstrukcją trwałą, po której mógłby kursować planowany tramwaj elektryczny. Powołana przez magistrat miasta Lublina komisja zadecydowała o budowie nowego mostu o konstrukcji z betonu uzbrojonego i „poruczyła tę robotę w drodze licytacyi firmie Arnold Bronikowski i S-ka w Warszawie, za 15273 rub.", z terminem zakończenia robót do 29 lipca $1903 \mathrm{r}^{33}$.

Wszystko wskazywało, że roboty rozpoczęte w kwietniu zakończą się w terminie, „lecz przed samym odbiorem sklepienie pękło". Szczegółowa analiza przebiegu zdarzeń ukazuje, że ustrój niosący mostu ulegał awarii dwukrotnie. Po raz pierwszy żelbetowy łuk zarysował się, gdy po 24 dniach od zabetonowania zwolniono kliny, na których opierało się jego deskowanie. Komisja z magistratu miasta Lublina uznała wówczas, że beton nie osiągnął wymaganej wytrzymałości i nakazała jego rozbiórkę. Łuk został ponownie wykonany pod ścisłym nadzorem inwestora, lecz po zasypaniu ugiął się w kluczu o $16 \mathrm{~cm}$ bez zarysowania. Ponownie w „celu zbadania przyczyny wypadku i zarządzenia naprawy, wyznaczono komisyę złożoną z pp. Czerniawskiego, kapitana Marczeńki, inż. Sikorskiego i bud. Paprockiego. Komisya ta zarządziła wzmocnienie przyczółków" lub wymianę za- 
sypki na piaskową. Pomimo wykonania zaleconych przez komisję robót na przyczółkach, 20 października 1903 r. lubelski most zawalił się $e^{34}$.

Wiadomość o katastrofie lubelskiego mostu upubliczniła agencja z Moskwy, a za nią wydawana na Górnym Śląsku w Bytomiu gazetka tygodniowa dla ludu polsko-katolickiego o nazwie „Gwiazda”, która donosiła: „W Lublinie w Królestwie Polskiem w piątek o godzinie 9 rano zawalił się most na rzece Cechówce, przy ulicy Lubartowskiej [...] Most miał być za kilka dni oddany do użytku"35.

Już 27 października 1903 r. inż. A. Rosset, który przewodniczył Warszawskiej Sekcyi Technicznej, zaproponował poruszenie na przyszłym posiedzeniu aktualnego tematu: „zawalenie się mostu w Lublinie systemu Monier'a i zawalenie się mostu innego systemu żelazobetonowego we Lwowie" w formie komunikatu ${ }^{36}$. W konsekwencji na kolejnym posiedzeniu dnia 30 października 1903 r. temat katastrofy mostu był omawiany przez inż. Łatkiewicza, który odpowiadając na pytanie pana Grabowskiego o przyczynę zawalenia się mostu w Lublinie, wyjaśnił „że most ten zbudowany był zupełnie prawidłowo, a powodem załamania się było pojawienie się wód podskórnych, choć pierwotne sondowanie ich nie wykazało. Wody te spowodowały osunięcie się filaru, a w następstwie pęknięcie sklepienia pośrodku"37.

Zapewne informacje inż. Łatkiewicza okazały się niewystarczające, ponieważ w dniu 17 listopada 1903 r. Warszawska Sekcya Techniczna, której przewodniczył inż. A. Rosset, omawiała po raz kolejny to zdarzenie. Po odczytaniu przez przewodniczącego sprawozdania rzeczowego w sprawie zawalenia się mostu w Lublinie, wystąpił obecny na posiedzeniu inż. Arnold Bronikowski, który wyjaśnił, że przyczółki mostu zaprojektowano i wykonano w oparciu o wyniki urzędowego badania gruntu, przekazane jego firmie przez magistrat miasta Lublina. Badania te wykazały „na głębokości do 2-ch saż. $(=4,25 \mathrm{~m})$ grunt grzązki, niestały, a głębiej twardy ił". Na podstawie tych informacji konstrukcje przyczółków posadowiono

każdy na 24-ch palach po 3 saż. $(=6,4 \mathrm{~m})$ długości, wbitych 30-pudowym (=490kg) kafarem aż do odskoku i powiązanych u wierzchu pomiędzy sobą podwójnym rusztem dębowym. Nadto otoczono to rusztowanie wokoło szpuntowanemi ścianami zabitemi do 3 saż. $(=6,4 \mathrm{~m})$ głębokości. Na takich rusztach zbudowano fundamenty i przyczółki z betonu granitowego 1:4:6, ściśle według zatwierdzonego projektu i pod ścisłym nadzorem budowniczych miejskich i gubernialnych. Na tych przyczółkach, po upływie około 5-ciu tygodni, oparto łuk mostu, o rozpiętości 6 saż. $(=12 \mathrm{~m})$ i 0,60 saż. $(=1,3 \mathrm{~m})$ strzałki, grubości w kluczu $20 \mathrm{~cm}$ i w oporach $30 \mathrm{~cm}, \mathrm{z}$ betonu piaskowego 1:3 i podwójnej siatce żelaznej.

Ponieważ żelbetowy łuk mostu „dał przegięcie w kluczu o 16 cm”, wykonawca robót nabrał podejrzeń, że wystąpiło osiadanie jednego z przyczółków i nie zgodził się na próbne obciążenie mostu. Pomimo zalecenia przez wspomnianą komisję i wykonania przez 
wykonawcę robót piaskowej zasypki przyczółków, ustrój niosący zarysował się od spodu, „aż wreszcie w przeddzień urzędowej próby łuk wpadł do rzeki"38.

Przebieg posiedzeń Warszawskiej Sekcyi Technicznej wraz ze szczegółowymi informacjami technicznymi na ten temat został opublikowany w dwóch numerach „Przeglądu Technicznego" w rubryce zatytułowanej „Z Towarzystw Technicznych”. Po wzmocnieniu fundamentów i wykonaniu nowego ustroju niosącego roboty zakończono w 1904 r. O tym wydarzeniu 15 września poinformowała „Gazeta Lubelska”. „Most na rzece Czechówce, przy ulicy Lubartowskiej, został nareszcie (po dwukrotnych zawaleniach się) wybudowany, wypróbowany i ruch po nim wkrótce zostanie otwarty"39. Nastąpiło to z rocznym opóźnieniem ${ }^{40}$.

Most przez Czechówkę w Lublinie nie zachował się do naszych czasów. Zapewne został rozebrany w dwudziestoleciu międzywojennym w związku ze skanalizowaniem rzeki.

Wiadukt na ulicy Karowej w Warszawie był kolejnym obiektem inżynierskim zbudowanym w systemie Moniera. Można go uznać za największe osiągnięcie Biura Technicznego Arnold Bronikowski \& S-ka Inżynierowie. Magistrat miasta Warszawy przygotowywał się do tej budowy już od 1898 r., „gdy wraz z rozpoczęciem budowy hotelu Bristol zburzono bramę, prowadzącą z Krakowskiego Przedmieścia, zdobną w herb miasta Syrenę i dwie studnie wodociągowe z paszczami Iwiemi, wydatkując na ten cel pierwsze 15000 rubli"41. Inżynier Bronikowski spodziewał się powierzenia mu robót mostowych na Karowej już w 1902 r., na co wskazuje notatka w „Gazecie Kaliskiej” z 26 lipca tego roku, z której dowiadujemy się, że jego biuro „obok całego szeregu podobnych mostów w Warszawie, Łodzi, Połtusku i. t. d., w ostatnich kilku latach wykonanych, przystąpi w r. b. do budowy wiaduktu na ulicy Karowej (za hotelem Bristol) w Warszawie"42. O podjęciu decyzji poinformował 9 lutego 1903 r. „Kurjer Warszawski” w następujący sposób: „Senat rządzący zatwierdził opracowany przez magistrat $\mathrm{m}$. Warszawy projekt budowy mostu-wiaduktu na ul. Karowej. Wykonanie tej przyszłej ozdoby miasta powierzono firmie A. Bronikowski za sumę 90,510 rubli"43.

Wiadukt w ciągu ul. Karowej miał zostać zlokalizowany w łuku o promieniu $45 \mathrm{~m}$ w ciągu tzw. ślimaka umożliwiającego zjazd z wysokiej wiślanej skarpy na Powiśle. Koncepcję urbanistyczną tego zjazdu jeszcze w 1897 r. opracował inż. Kajetan Mościcki (1855-1933), który pełnił wówczas funkcję Naczelnego Inżyniera miasta Warszawy. To bardzo wówczas oryginalne rozwiązanie przebiegu ul. Karowej zostało opisane w piśmie „Życie i Sztuka” w następujący sposób: „Potem ta ulica zniża się, zakręca, prowadzi na wiadukt, na dwóch potężnych arkadach oparty i, zniżając się ciągle spadkiem wolnym i łagodnym, zjeżdża łukiem koła o dużem promieniu w ten sposób, że zawraca pod arkady

38 „Przegląd Techniczny” r. 29, 1903, nr 47, s. 650-651.

39 "Gazeta Lubelska” r. 30, 1904, nr 199, s. 2. J. Żywicki w artykule Początki budownictwa żelbetowego w Lublinie, „Kwartalnik Historii Kultury Materialnej” t. 65, 2017, nr 1, s. 63, podaje informację, że ustrój niosący odbudowanego mostu wykonano z żelaza.

40 A. Kierek, Rozwój przestrzenny i stan urządzeń komunalnych m. Lublina w latach 1870-1915, „Rocznik Lubelski" t. 4, 1961, s. 171-214.

41 „Kurjer Warszawski” r. 84, 1904, nr 344, s. 9.

42 „Gazeta Kaliska” r. 10, 1902, nr 199, s. 2. Nie odnaleziono dokumentów źródłowych dotyczących mostów zbudowanych przez biuro techniczne inż. A. Bronikowskiego w Łodzi i Pułtusku.

43 „Kurjer Warszawski” r. 83, 1903, nr 40, s. 5. 


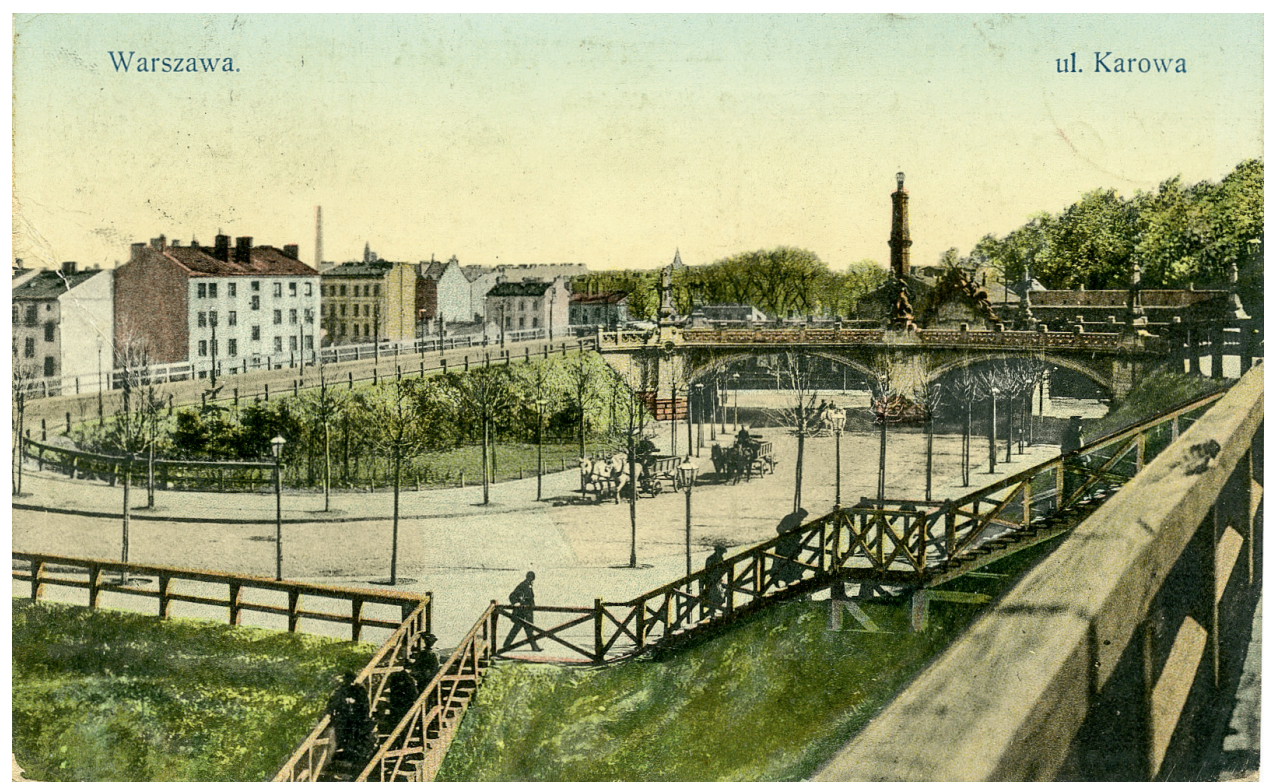

Fot. 7. Ślimak zjazdowy ze skarpy wiślanej na pocztówce wysłanej 1 września 1911 r. do Waszyngtonu D. C., Wydawnictwo K. Wojutyńskiego w Warszawie (ze zbiorów autora).

wiaduktu"44. Autorstwo drogowych projektów wykonawczych jest przypisywane inż. Kazimierzowi Dankowskiemu, który w latach 1900-1903 kierował realizacją robót ziemnych na zjeździe ${ }^{45}$.

Zgodnie ze stanem faktycznym, stwierdzonym w 2004 r. przez dr. inż. Andrzeja Mareckiego, pomost wiaduktu o szerokości 22,90 m pomieścił jezdnię o szerokości 11,20 m i obustronne chodniki po 4,82 m. Dla dostosowania kształtu wiaduktu do tzw. ślimaka, inżynierowie A. Bronikowski i K. Sommer zaprojektowali żelbetową konstrukcję o dwóch przęsłach łukowych, opartych na środkowym filarze o zmiennej szerokości: od 3,76 m w elewacji zachodniej do 14,98 m w elewacji wschodniej. W szerszej części filara wygospodarowali trójkątne pomieszczenie, które przekryli dodatkowym siedmiometrowym sklepieniem ${ }^{46}$. Z „Książki Obiektu Mostowego" dowiadujemy się, że obecnie długość wiaduktu wynosi $35 \mathrm{~m}$, a rozpiętości teoretyczne przęseł 12,84 i 13,16 m7. Wystrój architektoniczny wiaduktu zaprojektował w 1902 r. warszawski architekt Stefan Szyller (18571933) w stylu akademickiego historyzmu końcowych lat XIX w. ${ }^{48}$.

Projektowanie wiaduktu rozpoczęto jeszcze w 1900 r., a po jego zakończeniu w lipcu 1902 r. wysłano projekt do Petersburga celem zatwierdzenia przez władze Imperium Rosyjskiego. Budowę wiaduktu można było rozpocząć po uzyskaniu pozytywnej decyzji i po zakończeniu okresu zimowego - dopiero wiosną 1903 r. W tym samym roku zakoń-

44 „Życie i Sztuka” 1904, nr 46, s. 10-11.

45 M. Kałamajska-Saeed, Wiadukt ulicy Karowej w Warszawie, „Kwartalnik Architektury i Urbanistyki” r. 22, 1977, nr 2, s. 158.

46 A. Marecki, Remont wiaduktu im. Stanisława Markiewicza na ul. Karowej w Warszawie, „Wiadomości Konserwatorskie" 2005, nr 17, s. 87-90.

47 Zarząd Dróg Miejskich, Warszawa, „Książka Obiektu Mostowego” JNI:20002003, 2000 r.

48 M. Kałamajska-Saeed, op. cit., s. 155. 


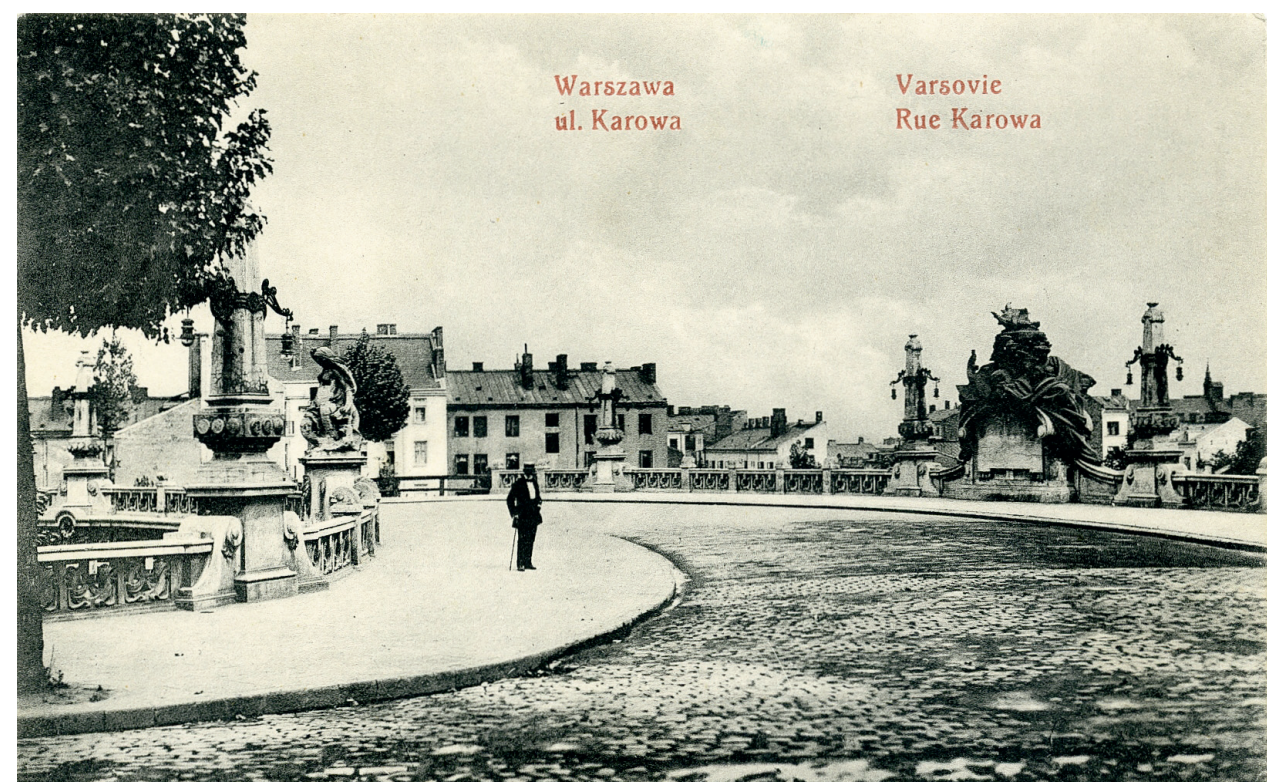

Fot. 8. Wystrój rzeźbiarski wiaduktu na ul. Karowej w wersji początkowej na pocztówce bez obiegu, Chlebowski i Michałowski p. f. Świt w Warszawie (ze zbiorów autora).

czono budowę sklepienia pierwszego przęsła, a w czerwcu 1904 r. sklepienia przęsła drugiego ${ }^{49}$.

W czasie, gdy kończyły się roboty konstrukcyjne, jak również zimą 1904/1905 r., cieszący się powszechnym uznaniem artysta Jan Woydyga (1857-1938?) pracował nad rzeźbiarskim wystrojem wiaduktu, któremu z własnej inwencji nadał cechy charakterystyczne dla secesji. Jego pracownia mieściła się pod przęstem wiaduktu, położonym od strony Krakowskiego Przedmieścia ${ }^{50}$. Spośród wykonanych przez niego rzeźb, które pierwotnie odlano z cynku, a po 1911 r. wymieniono na kamienne, szczególną uwagę przykuwa grupa alegoryczna usytuowana w centralnym punkcie południowej balustrady wiaduktu. Została skomponowana wokół płonącego znicza w girlandach dębowych liści z dwóch siedzących postaci: po prawej stronie - pięknej kobiety personifikującej Warszawę z atrybutami nauki i sztuki, po lewej - muskularnego mężczyzny z symbolami przemysłu i rolnictwa. W centralnie umieszczonym medalionie umieszczono maskę brodatego wodnika, który wyobraża rzekę Wisłę. Na północnej balustradzie ustawiono rzeźbę wyłaniającej się ze spienionych fal syreny, symbolizującej Warszawę̨ ${ }^{51}$.

O dopuszczeniu wiaduktu do ruchu dowiadujemy się z popołudniowego wydania Kurjera Warszawskiego z 12 grudnia 1904 r., w którym czytamy:

Od wczoraj przejazd z Krakowskiego Przedmieścia na Powiśle wiaduktem, zbudowanym w połowie ulicy Karowej, otwarto, aczkolwiek nie wszystkie roboty są

49 Ibid., s. 153

50 „Kurjer Warszawski” r. 84, 1904, nr 344, s. 9.

51 A. Kasprzak-Miler, Wiadukt im. Stanisława Markiewicza na ul. Karowej w Warszawie - jego remont i konserwacja, Warszawa 2011, s. 154-163; patrz także: M. Kałamajska-Saeed, op. cit., s. 155. 


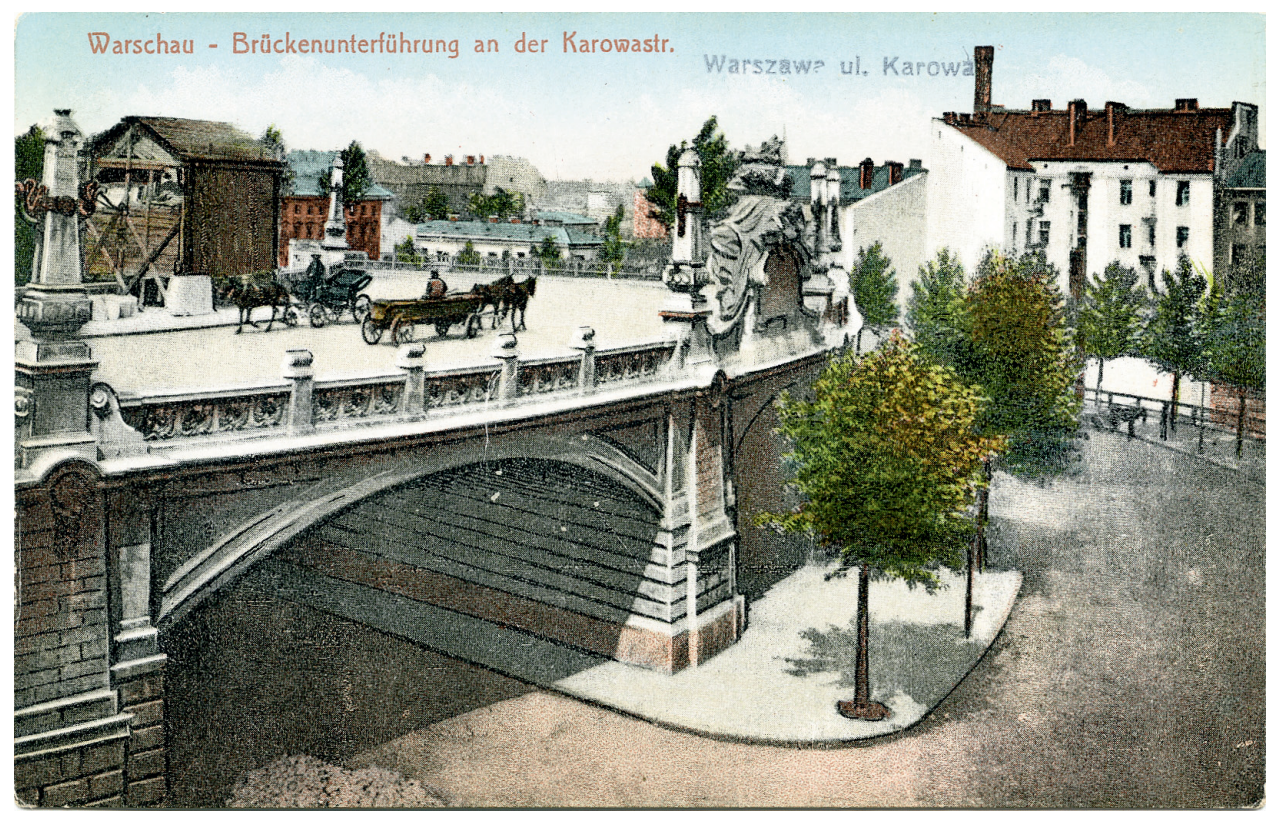

Fot. 9. Wiadukt na Karowej po zajęciu Warszawy przez Niemców w okresie pierwszej wojny światowej na pocztówce bez obiegu, bez wydawcy (ze zbiorów autora).

jeszcze ukończone. Mianowicie: w dalszym ciągu brukuje się jeszcze szkarpy świeżych nasypów, układają ponownie chodniki z płyt betonowych w miejscach, gdzie grunt osiadł, na samym zaś wiadukcie stają betonowe ogrodzenia, tymczasowo zastąpione drzewem, zakładane są latarnie na ozdobnych rzeźbionych słupach, oraz wykończa się roboty zdobnicze wiaduktu.

Koszt prowadzonej od 1898 r. inwestycji wyniósł 250 tys. rubli rosyjskich (w tym 51235 rubli na wykup gruntu od Klasztoru Wizytek) i został pokryty w całości przez magistrat miasta Warszawy ${ }^{52}$.

Wiadukt, oddany do użytku 11 grudnia 1904 r., nazwany potem imieniem Stanisława Markiewicza, przetrwał bez zniszczeń dwie wojny światowe i Powstanie Warszawskie 1944 r., a w 2006 r. został jako zabytek zrewaloryzowany przez Zarząd Dróg Miejskich miasta stołecznego Warszawy.

Biuro Techniczne Arnold Bronikowski \& S-ka Inżynierowie wykonywało również projekty sieci wodociągowych i kanalizacyjnych. Jednym z pierwszych był projekt koncepcyjny budowy wodociągów dla Łodzi, wymagający nakładów w wysokości 2500 tys. rubli rosyjskich, który w 1889 r. opracowali inżynierowie Józef Słowikowski, Arnold Bronikowski i Sommer. Zaprojektowali ujęcie wody na rzece Grabi w odległości 27 wiorst od Łodzij3. W 1898 r. biuro inż. Bronikowskiego przeprowadziło wstępne badania geologiczne w celu właściwe-

52 „Kurjer Warszawski” r. 84, 1904, nr 344, s. 9.

53 B. Kowalska-Wajnkaim, 85 lat historii wodociągów i kanalizacji w Łodzi / asenizacyjno-wodna epopeja łódzka, www.dev.zwik.lodz.pl/wgrane_pliki/85lat.pdf [dostęp 30.08.2018], s. 27. 


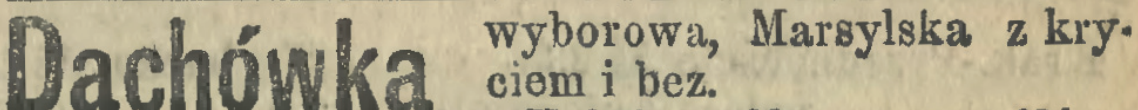

Fot. 10. Fragment strony „Kurjera Warszawskiego" z 1901 r. z reklamą zamieszczoną przez inż. Bronikowskiego (Biblioteka Uniwersytetu Warszawskiego).

go zlokalizowania ujęcia wody dla Kielc ${ }^{54}$. Dwa lata później w biurze technicznym powstał najstarszy znany projekt wodociągu dla Radomia, którego koszt budowy oszacowano na 803 tys. rubli i projekt kanalizacji o przewidywanych kosztach 411 tys. rubli55. Większość z projektów nie doczekała się realizacji bezpośrednio po ich opracowaniu. Po latach podejmowano prace już według innych konkurencyjnych projektów, w szczególności autorstwa, uznanego za autorytet tamtych czasów, inżyniera Wiliama Heerleina Lindley'a.

Dla podreperowania finansowej kondycji Arnold Bronikowski już w 1897 r. zaczął handlować cegłą ogniotrwałą z fabryki Ostrowieckiej inżyniera Klepackiego, samosmarującymi pakunkami „Karmal” do maszyn parowych i wodnych oraz wszelkimi odlewami żelaznymi: filarami, balustradami, schodami z fabryki „Bliżyn”56. Potem w 1901 r. oferował sprzedaż dachówki wyborowej marsylskiej i usługę krycia nią dachów. W dotyczącej tej działalności reklamie, publikowanej w „Kurjerze Warszawskim”, pojawia się nowy adres firmy na ul. Książęcej nr 1157. Taka działalność prowadzona przez Bronikowskiego herbu Osęk, określana wówczas mianem kupieckiej, była źle postrzegana przez jego ziemiańską familię. Wnuk Stanisławy Katarzyny Prądzyńskiej herbu Grzymała (1890-1980) wspomina, że kiedy jego babcia jechała karetą ulicami Warszawy zasłaniała oczy, żeby nie widzieć reklam wywieszonych przez swojego krewnego ${ }^{58}$.

Inżynier Arnold Bronikowski zmarł w 1907 r. w wieku 61 lat. Jego przyjaciel, inż. Emil Sokal (1851-1928), dyrektor warszawskiej Stacji Filtrów, we wspomnieniu pośmiertnym napisał następujące słowa:

Ś. p. ARNOLD BRONIKOWSKI był dobrym inżynierem, lecz kupcem, niestety, jak większa część kolegów naszych - nie był. To też niepowodzenia natury materyalnej przecięły za wcześnie tę nić pracowitego żywota, a tych kilka słów wspomnienia od kolegi z ławy szkolnej zamiast kwiatów na świeży grób przesyłam Redakcyi Przeglądu Technicznego ${ }^{59}$.

Po Arnoldzie Bronikowskim pozostały do dziś wspomnienia i trzy piękne mosty, które przetrwały wojenne pożogi.

54 J. Pazdur, Dzieje Kielc 1864-1939, Wrocław 1971, s. 24.

55 Z. Wilczyński, Wodociągi i kanalizacja miasta Radomia 1927-1977, „Biuletyn Kwartalny Radomskiego Towarzystwa Naukowego" t. 14, 1977 r., z. 1, s. 13-15.

56 „Tygodnik Illustrowany" 1897, nr 35, s. bez nr.

57 „Kurjer Warszawski” r. 81, 1901, nr 282, Dodatek poranny, s. 3.

58 Relacja Andrzeja Radoszewskiego przekazana autorowi 23 II 2018 r.

59 E. Sokal, op. cit. 
Bibliografia

\section{Materiały źródłowe}

Wojewódzki Urząd Ochrony Zabytków w Warszawie:

sygn. -N./War.1101 Dokumentacja prac konserwatorskich mostku żelbetowego z żelazną balustradą w parku Ujazdowskim w Warszawie, Warszawa 1988/89,

sygn. T.2484 A. Park Ujazdowski Warszawa Aleje Ujazdowskie 6. Recenzja ewidencji parku, autorzy: mgr inż. Zofia Piekarska, mgr inż. Zofia Ziembińska-Sznee, 1988.

Urząd Miejski w Kaliszu, „Karta Adresowa Zabytku Nieruchomego” nr 12777: Most Reformacki na Kanale Rypinowskim, 28 VII 2012 r.

Miejski Zarząd Dróg i Komunikacji w Kaliszu „Książka Obiektu Mostowego” JNI:01028013, Most Reformacki 2000 r.

Zarząd Dróg Miejskich - Wydział Mostowy, Warszawa, „Książka Obiektu Mostowego” JNI:20002003, wiadukt ul. Karowa, 2000 r.

\section{Źródła prasowe}

"Gazeta Kaliska: informacyjno-anonsowa":

r. 10, nr 199, 26 VII 1902 r., s. 2,

r. $10, \mathrm{nr} 259,13 \mathrm{IX} 1902$ r., s. 2,

r. $10, \mathrm{nr} 280,17 \times 1902$ r., s. 2 ,

r. $10, \mathrm{nr} 286,23 \times 1902$ r., s. 1 ,

r. 10, nr 295, 1 XI 1902 r., s. 2.

„Gazeta Lubelska”, r. 30, nr 199, 15 IX 1904 r., s. 2.

"Gwiazda. Gazetka tygodniowa dla ludu polsko-katolickiego", r. 1, nr 20, 8 XI 1903 r., s. 7.

„Kurjer Warszawski":

r. $77, \mathrm{nr} 170,22$ VI 1897 r., s. 4-5,

r. 77, nr 214, 5 VIII 1897 r., s. 3,

r. $77, \mathrm{nr} 286,16 \times 1897$ r., s. 6 ,

r. 78, nr 138, 20 V 1898 r., s. 4,

r. 81, nr 282, Dodatek poranny, (29 IX 1901 r., s. 3,

r. 83, nr 40, 9 II 1903 r., s. 5,

r. 84, nr 344, 12 XII 1904 r., s. 9.

„Prawda. Tygodnik Polityczny, Społeczny i Literacki” r. 11, nr 15, 11 IV 1891 r., s. 180.

"Przegląd Techniczny":

r. $24, \mathrm{nr} 41,8$ X 1898, s. 685-691,

r. 29, nr 44, 5 XI 1903, s. 621,

r. 29, nr 47, 26 XI 1903, s. 650-651,

r. $38, \mathrm{nr} 41,10 \times 1912$, s. 933 ,

r. 33, nr 46, 14 XI 1907, s. 554.

„Tygodnik Illustrowany":

24 VIII 1895, nr 34, strona bez numeru,

28 VIII 1897, nr 35, strona bez numeru.

„Życie i Sztuka. Pismo dodatkowe, ilustrowane. Kraj" 25 XI 1904, nr 46, s. 10-11. 


\section{Literatura przedmiotu}

Biliszczuk J., Mosty w dziejach Polski, Wrocław 2017.

Jankowski J., Mosty w Polsce i mostowcy polscy (od czasów najdawniejszych do końca I wojny światowej), Wrocław 1973.

Kałamajska-Saeed M., Wiadukt ulicy Karowej w Warszawie, „Kwartalnik Architektury i Urbanistyki" r. 22, 1977, nr 2, s. 149-160.

Kasprzak-Miler A., Wiadukt im. Stanisława Markiewicza na ul. Karowej w Warszawie - jego remont i konserwacja, [w:] Architektura znaczeń. Studia ofiarowane prof. Zbigniewowi Bani w 65. rocznicę urodzin i w 40-lecie pracy dydaktycznej, Warszawa 2011, s. 154-163.

Kierek A., Rozwój przestrzenny i stan urządzeń komunalnych $m$. Lublina $w$ latach 1870-1915, „Rocznik Lubelski” t. 4, 1961, s. 171-214.

Kilby J., Noyce R., Inventors and Inventions Volume 4, New York 2008.

Kowalska-Wajnkaim B., 85 lat historii wodociągów $i$ kanalizacji w Lodzi / asenizacyjno-wodna epopeja tódzka, www.dev.zwik.lodz.pl/wgrane_pliki/85lat.pdf [dostęp 30.08.2018].

Kozielski A., Mostek w Parku Ujazdowskim w Warszawie - przykład wczesnej konstrukcji żelbetowej, „Ochrona Zabytków 1986, nr 1, s. 38-42.

Marecki A., Remont wiaduktu im. Stanisława Markiewicza na ul. Karowej w Warszawie, „Wiadomości Konserwatorskie” 2005, nr 17, s. 87-90.

Pazdur J., Dzieje Kielc 1864-1939, Wrocław 1971.

Rybak M., Zanim minął wiek XIX - były już mosty z betonu zbrojonego, „Drogownictwo" 2002, nr 7-8, s. 226-237.

Tabaka A., Błachowicz M., Most Reformacki 1902, „Życie Kalisza”, www.zyciekalisza. $\mathrm{pl} /$ ?str=82\&id=157107 [dostęp 30.08.2018].

Thullie M., Mosty żelbetowe, Lwów 1921.

Wilczyński Z., Wodociągi i kanalizacja miasta Radomia 1927-1977, „Biuletyn Kwartalny Radomskiego Towarzystwa Naukowego" t. 14, 1977, z. 1, s. 13-15.

Żywicki J., Początki budownictwa żelbetowego w Lublinie, „Kwartalnik Historii Kultury Materialnej" t. 65, 2017, nr 1.

Dr inż. MAREK MISTEWICZ jest pracownikiem naukowym Instytutu Badawczego Dróg i Mostów w Warszawie. Ukończył studia wyższe na Wydziale Inżynierii Lądowej Politechniki Warszawskiej, a w 2012 r. obronił rozprawę doktorską na Wydziale Architektury tej samej uczelni. Pełnił między innymi funkcje: Naczelnego Dyrektora Zarządu Dróg Miejskich w Warszawie, Prezesa Biura Projektowo-Badawczego Dróg i Mostów Transprojekt-Warszawa Sp. z o.o. oraz Zastępcy Generalnego Dyrektora Dróg Publicznych. Jest autorem dwóch monografii z dziedziny historii techniki oraz około osiemdziesięciu artykułów w czasopismach naukowych i naukowo-technicznych, rozdziałów w książkach i referatów opublikowanych w księgach konferencyjnych, na tematy związane m. in. z: teorią zarządzania mostami, utrzymaniem dróg i mostów oraz historią techniki mostowej. E-mail: mmistewicz@ibdim.edu.pl 